\title{
Further Notes on Kula Ring Calendrics-and Megaliths? Towards an Archaeology of Austronesian East Asian Connections
}

\author{
Damon Frederick $H^{*}$ \\ Department of Anthropology, University of Virginia, USA
}

Submission: May 22, 2018; Published: June 26, 2018

*Corresponding author: Damon Frederick H, Department of Anthropology, University of Virginia, USA, Tel: 434-295-6774;

Email: fhd@virginia.edu

Abstract

A brief return to investigate a hypothesis about the relationship between Chinese astronomical beliefs and spatial concepts in the Kula Ring in eastern Papua New Guinea turned up a new understanding of fundamental cosmological principles on Muyuw, also known as Woodlark Island. This preliminary account outlines what was learned. Although spatial and temporal forms vary throughout the Kula Ring, the region is understood as a totality and as such shares ideological structures common to the Austronesian expanse across the Indo-Pacific. If the material reported here can be sustained by other inquiries, then a new understanding of Oceanic societies will follow.

Keywords: Archaeology; Megaliths; Calendrics; Cosmology; West; Woodlark Island; Temple; Indo-Pacific; Social structure; Anthropological; Lodges; Mansions; Language; Astronomy; History

"So present was this divine and celestial character to the Polynesian mind that they called the chiefs lani, heaven, and the same word marae is used of a temple and a chief's grave' (Hocart [1927] 1969:11)" [1].

\section{Short Communication}

This short communication concerns the social structure and cosmology of what is known as the Kula Ring in Milne Bay Province, Papua New Guinea. The data and ideas presented are a preliminary statement and synthesis of known material. While they require more research for this specific case, they also suggest lines of interpretation and research for many other areas. The Kula Ring has been a classic region in the anthropological world of since Bronislaw Malinowski ethnographic writings on the Trobriand Islands [2], and one of the empirical centres for the reworking of exchange theory from the 1970s and 1980s [3-7]. Recent archaeological work is transforming our understanding of the area [8-13]. Although inhabitants of the region's southeastern most point, Rossel Island, speak a non-Austronesian language and may, therefore, reflect human occupation for over 20,000 years, most people speak Austronesian languages. Therefore they represent social and linguistic transformations dating inside the last 3000 years [14]. The region forms a cluster of Austronesian languages belonging to a group labelled Papuan Tip. And exclusive of some of the Rossel Island work, much of the region's archaeology is consistent with this relatively recent time frame. It is presumed Austronesian speakers absorbed characteristics of original Papuan languages which are not seen elsewhere in near or Remote Oceania. Although some archaeological research suggests the practices that have made the region famous are quite recent, data outlined here suggests ties to the time megaliths were built across the northern side of the Kula Ring, thus beginning perhaps 1500BP. Much social/ cultural anthropological research tended to be village focused and therefore indifferent to regional relationships. However, the new material discussed in this report leads to a macrounderstanding of the entire Kula Ring area. Not coincidentally, some of this new work is stimulated by recent studies of ancient Chinese Astronomy. Of particular relevance is Pankenier's work showing how ancient Chinese society organized itself by trying to replicate on earth patterns it projected into the heavens [15].

From this data two broad possibilities flow. First, ideas now associated primarily with ancient Chinese culture circulated continuously and through the Austronesian expansion across the Indo-Pacific. That possibility is consistent with the history of Southeast Asia over the last 2000 years. However, there is no convincing evidence of direct Asian forays east of New Britain. A second possibility is that ideas now associated with Chinese 
history inside the last 3-4000 years were, in fact, relatively wellformed much earlier than that. They may thus have been part of the original cultural repertoire of the people who became Austronesians.Hypothetically, some proximate model of what is suggested here was internal to Austronesian parent cultures in what is now Fujian Province. It was then taken to what is now Taiwan, roughly 6000 years ago. In this scenario, evident similarities across the Indo-Pacific are, in fact, the working out of old paradigms in new ecological contexts. Since the received synthesis of Chinese history locates it north of the Yangtze River this possibility has major implications not only for the understanding of Oceanic societies, but also the cultural history, and structure, of 'China.'

Three sets of new facts support these possibilities.

First, some elder Muyuw people in the northeast corner of the Kula Ring assert that the region's highest island is Rossel Island in the southeast corner while the lowest are the Trobriand Islands in the northwest corner. In this model Muyuw and Goodenough Islands, the northeast and southwest respectively, are roughly the same height, midway between the Rossel/Trobriand extremes. Inside the Kula Ring this model is interesting because the ascribed vertical elevation precisely inverts widely recognized social status. Even though they are the source for one of the two primary Kula valuables, everyone knows people on Rossel Island speak a strange, isolating language and do not participate in the Kula exchange system. And everyone knows that the Trobriands have a peculiarly high social status. They also know that Rossel Island is not literally the highest island in the region. Virtually all of mountainous islands from Normanby to Goodenough exceed Rossel in absolute elevation. Rather than a literal description of a physical reality, this model uses conceived verticality to totalize a field of social relations.Analogous spatial models totalized many aspects of Chinese society.

Consistent with this well-formed model of islands in space, named star sets, for the most part constellations, are configured about the horizon so that all major islands can be related to star positions. Whatever the extent of this conceptual system, it was used for navigation. Routes between islands are usually pegged to an asterism's rise in the east, occasionally its setting in the west. With the exception of what we call the Southern Cross and a visible portion of the Big Dipper, stars are likened to trees in the sky, the eastern rising point the base, the western setting point the tip of the tree, familiar Austronesian reference points. In contrast to the east-to-west movement of most stars, the Southern Cross and Big Dipper are conceived to arc about points to the south and north, respectively larger and smaller arcs.

The Chinese model of the heavens was North-Pole centric; the Muyuw analogue is bipolar. The rising or setting points for all stars or constellations are called in Muyuw kaban, or keb, in either case connoting a sitting or resting places.These points are similar to what are called "Mansions" or "Lodges" in the Chinese system of ÈrshíbāXiù, Twenty-eight Overnights. The "routes," kut, configured with respect to these positions are understood to be in the sky. However, it is explicit that the boat following the route is on the water. The surface route thus conforms to a pattern in the sky. This is, in fact, a pervasive understanding, witnessed in the ways star motions should organize gardening sequences, boat and sail imagery, and the dress of important people, men in particular. Much of this is outlined in Damon [17], though that work was completed before data was obtained that stimulates this presentation. But important men in particular were to be seen with combs stuck in their hair. These combs might be 30 or more centimetres long and held in the hair by the comb's teeth.

What is translated as "comb" here is called sinat in the Muyuw language, and this is also the name for the constellation the West calls Scorpius, its fanning stars equivalent to the comb's teeth. If an important person was making a statement by being dressed up he tied to the end of his comb handle the leaf of an orchid-like plant (perhaps ORCHIDACEAE Bulbophyllum sp.) obtained from sago orchard swamps. First dried in the sun, these pliable, leathery leaves had etched into their surfaces designs fractally encompassed 4-point rhombus shapes-that are called utun, "star" or "constellation." When tied to the comb end the leaf would flutter in the wind or as the person walked. In either case the imagery is likened to the twinkling of stars which are especially pronounced when a star rises in the east or sets in the west. Such twinkling evidences a star's power, as well as that of the person wearing the form. Pandanus leaves tied to various boat edges, and in particular to the sail, were also understood to reflect the star-like power associated with boats. In fact all winds, which of course propelled the craft, are associated with stars. Efficacy in this world comes from patterns in the sky.

Nowhere is this coupling of the heavens and earth more apparent, or more important, than in the structure of the Muyuw garden. I have discussed these forms in major publications $[16,17]$, and likened them to structures Cunningham made memorable for the Atoni house [18], to invoke another organization in the Austronesian world. The form is conceived to have been defined by the culture's Creator, Geliu.The orientation is considered the condition for garden production, hence all life, and provides a model for marriage relations and the human life cycle by virtue of the growth of the crops it contains. Along with the structure of the culture's most important outrigger canoe form, which is superimposed over a garden, it is the culture's most important and thorough articulation of fundamental values[18].

In all previous descriptions of this form I have stressed that it is organized by the conceived direction of the movement of the sun. Hence sunrise/sunset organizes the form, and not just the garden, but the ideal arrangement of the island at large, villages and houses in villages. So gardens are first defined by an "east" to "west" path. That path must be bisected by a "north"/"south" path.Although gardens may have two bisecting paths and thus appear square with four virtually identical "sections," most have 
more than one "north"/"south" path and thus are rectangular in shape. The intersection of the east/west and north/south paths constitutes a model of marriage relations articulated with respect to a social unit called kum, in the anthropological literature translated as (matrilineal) clan[19-21]. Four clans are associated with the four primary directions. They are considered to be in symmetrical relationship with each other with respect to the exchange of women or men-i.e. a woman for a woman and a man for a man.These person exchanges provide models for all other relationships associated with life-cycle transformations. The details of the modeled relations are explicitly related to the initial orientation of the garden, the model I had defined for me first of all in terms of the sun. I did not conceptualize this arrangement as an earthly representation of forms in the sky but given the aforementioned Pankenier work it is certainly that: 'earth' conforming to “'heaven'[22-24]."

Each section is further subdivided by lines of cut and partially burned logs, branches or stones. These are called lapuiy, and long ago I learned that the Milky Way is likened to a lapuiy in the nighttime sky. Lapuiy are also conceived to follow the sun but just as importantly define quantitative units of yams and/or taro used for brother-to-sister exchanges. These exchanges form pivots around which life-cycle transformations become defined. If the apparently primary set of paths defines qualitative exchange relations, the subsidiary lapuiy lines, which define units called venay, organize quantitative relations which are realized in units called dal. This word translates to sub clan in the regional literature. Subclans are property holding and ceding units defined with respect to countable debts[25-28].

For years I was aware that what we called the Milky Way is considered a lapuiy in the sky. However, in 2017 I was explicitly told that garden lapuiy are meant to replicate the apparent direction of the Milky Way as it appears in the early nighttime sky of June, roughly a solstice time. And that as the Milky Way appears to shift its orientation from east-to-west to northeastto-southwest that latter direction becomes the model for the north/south path in the garden. My informants realized that the north/south path was not an exact replica of the northward veering Milky Way. But they were insistent that the idea was that the garden form attempted to model the form the Milky Way represented. The early evening sky in December is when the ne/sw orientation of the Milky Way is most visible. And while Scorpius (Sinat) dominates the nighttime sky around the June (and following) time frame that provides the east/west alignment in the garden, Orion's Belt (Kiyad) dominates the December (and following) nighttime sky. I have already noted that Scorpius/Sinat is used in the self-decoration of important powers in this region[29,30]. The name for Orion's Belt, kiyad, perhaps complements Scorpius. For it is also employed for the cross beam on outrigger canoes, connecting the hull to the outrigger float. This is a critical connection because it balances two of a boat's major dynamics, the sinking force of the hull and the rising effect of the hull.Scorpius and Orion's Belt intrigue because of their complementary brilliance, two dominant night time forms which in fact are never seen in the sky together. Appearing proximate to the equinoxes but dominating following solstice periods, they would seem to be ripe phenomena for expressing important human values.

\section{Concluding Comments}

In this presentation I have assembled old and new data that suggest an important sector of the Kula Ring conceived itself to be organized in relation to its understanding of astronomical phenomena, the sun, stars and Milky Way. Intimations of ideas like these are common across the Austronesian world and elsewhere of course. Future work in the Kula Ring will explore the limits of this analysis, and there is good reason to push this kind of work beyond this locale [31]. And with analyzes like these we may be getting to the point where we can trace the genealogy of ideas as readily as we can trace the genealogy of genes.

\section{References}

1. Sahlins Marshall (2017) "The original political society" in On Kings. by David Graeber, Marshall Sahlins (Eds.), Hau Books, Chicago, USA, p. 23-64.

2. Malinowski B (1922) Argonauts of the Western Pacific. Routledge and Sons, London, UK

3. Weiner Annette (1976) Women of Value, Men of Renown. University of Texas Press, Austin, USA.

4. Leach, Jerry W, Edmund R Leach (1983) The Kula: New Perspectives on Massim Exchange. Cambridge University Press, Cambridge, USA.

5. Gregory CA (2015) Gifts and Commodities. Hau Books University of Chicago Press, Chicago, USA.

6. Munn ND (1986) The Fame of Gawa: A Symbolic Study of Value Transformation in a Massim (Papua New Guinea) Society. Cambridge University Press, Cambridge, UK.

7. Strathern M (1988) The Gender of the Gift. University of California Press, USA.

8. Bickler Simon H, Baiva Ivuyo (2002) Megaliths of Muyuw (Woodlark Island), Milne Bay Province, PNG. Archaeol Oceania, Australasia, 37(1): 22-36.

9. Bickler Simon H (2006) Prehistoric stone monuments in the northern region of the Kula Ring. antiquity 80 (2006): 38-51.

10. Ambrose Wal, Fiona Petchey, Pamela Swadling, Harry Beran, Elizabeth Bonshek et al. (2012) Engraved prehistoric Conus shell valuables from southeastern Papua New Guinea: their antiquity, motifs and distribution Archaeol. Oceania 47: 113-132.

11.Shaw, Ben, Mathieu Leclerc, William Dickinson, Matthew Spriggs, Glenn R Summerhayes (2016) Identifying prehistoric trade networks in the Massim region, Papua New Guinea: Evidence frompetrographic and chemical compositional pottery analyses from Rossel and Nimowa Islands in the Louisiade Archipelago. Journal of Archaeological Science: Reports 6: 518-535.

12. Shaw, Ben, Michelle C Langley (2017) Investigating the development of prehistoric cultural practices in the Massim region of eastern Papua New Guinea: Insights from the manufacture and use of shell objects in the Louisiade Archipelago. Journal of Anthropological Archaeology 48: 149-165. 
13. Swadling Pamela, Polly Bence (2016) Changes in kula valuables and related supply linkages between the Massim and the South Papuan Coast between 1855 and 1915. Archaeology in Oceania, 51(1): 50-60.

14. Ross Malcom, Andrew Pawley, Meredith Osmond (2016) The lexicon of Proto Oceanic. The culture and environment of ancestral Oceanic society. Volume 5 - People: body and mind. Published by Asia-Pacific Linguistics, College of Asia and the Pacific, The Australian National University, Canberra ACT 2600, Australia.

15. Pankenier David (2013) Astrology and Cosmology in Early China: Conforming Earth to Heaven. Cambridge: Cambridge University Press, Cambridge, UK.

16. Damon (1990) From Muyuw to the Trobriands: Transformations Along the Northern Side of the Kula Ring. University of Arizona Press, Tucson, USA.

17. Damon (2017) Trees, Knots and Outriggers Environmental Knowledge in the Northeast Kula Ring. Berghahn Books, Newyork, USA.

18. Cunningham Clark (1964) Order in the Atoni House. Brijdragen tot de tall-land-en volkenkunde 120: 34-68.

19. Damon Frederick H (1979) Woodlark Island Megalithic Structures and Trenches: Towards an Interpretation." Archaeology \& Phys. Anthrop. In Oceania, Australasia, 14: 195-226.

20. Damon (1980) The Kula and generalised exchange: considering some unconsidered aspects of The Elementary Structures of Kinship. Man (n.s.) 15 (2): 267-293.

21. Damon (1982) Calendars and Calendrical Rites on the Northern Side of the Kula Ring. Oceania, Australia, 52(3): 221-239.

22. Damon (2002) Kula Valuables, the Problem of Value and the Production of Names. L'Homme April-June 162: 107-136.

23. John B Carlson, Jane M (2005) The Woodlark Island Calendar: Contexts for Interpretation. In SONGS FROM THE SKY: Indigenous Astronomical and Cosmological Traditions of the World. pp. 348-357.
24. (2015) Kula Ring, Anthropology of. In: James D Wright, International Encyclopedia of the Social \& Behavioral Sciences, (2 ${ }^{\text {nd }}$ edn), Elsevier, Oxford, UK, 13: 139-143.

25. Frederick H Damon, Roy Wagner (1989) Death Rituals and Life in the Societies of the Kula. DeKalb: Northern Illinois University Press, USA.

26. Mark S Mosko, Frederick H. Damon (2005) On the Order of 'Chaos' Social Anthropology \& the Science of 'Chaos. Berghahn Books, Newyork, USA.

27. Damon (1983) Further Notes on Woodlark Island Megaliths and Trenches. Indo-Pacific Prehistory Association Bulletin No.4: 100-113.

28. Dorofeeva-Litchmann Vera (2010) Mapping a 'Spiritual' Landscape: Representation of terrestrial space in the Shānhăijīng. In Political Frontiers, Ethnic Boundaries, and Human Geographies In Chinese History, Nicola Di Cosmo, Dong J Wyatt (Eds.), London and New York, pp. 35-79.

29. Granet Marcel (1933) The right and left in China. In: Rodney Needham (Eds.), Right and Left: Essays on Dual Symbolic Classification. Chicago and London: University of Chicago Press, USA, p. 43-58.

30. Kirch Patrick V, Clive Ruggles, Warren D Sharp (2013) The Pānānā or Sighting Wall at Hanamauloa, Kahikinui, Maui: Archaeological investigation of a possible navigational monument. Journal of the Polynesian Society 122: 45-68.

31. Gill Timothy M, Patrick V Kirch, Clive Ruggles, Alexander Baer (2015) Ideology, ceremony and calendar in pre-contact Hawai'i: Astronomical alignment of a stone enclosure on O'ahu suggests ceremonial use during the Makahiki season. Journal of the Polynesian Society. 124(3): 243-268.

\section{Your next submission with Juniper Publishers will reach you the below assets}

- Quality Editorial service

- Swift Peer Review

- Reprints availability

- E-prints Service

- Manuscript Podcast for convenient understanding

- Global attainment for your research

- Manuscript accessibility in different formats

( Pdf, E-pub, Full Text, Audio)

- Unceasing customer service

Track the below URL for one-step submission https://juniperpublishers.com/online-submission.php 